\title{
New Directions for Agricultural Research and Extension in the 1990 Farm Bill
}

\author{
Kathleen Merrigan \\ United States Senate Committee on Agriculture, Nutrition, and Forestry, \\ Washington, DC 20510
}

What a year (1990)! This was the longest the Congress stayed in session in an election year since before WWII. We worked ungodly hours.

Let me tell you a little about the 1990 Farm Bill. It weighs 14 pounds and is $\approx 2000$ pages. It is the largest bill ever to pass the U.S. Senate in its history. You may be surprised to learn that the Research Title is the largest title in the bill and took the longest time to negotiate. In other words, research and extension were viewed by Congress as very significant issues in this Farm Bill.

Some people were disappointed by the final outcome on the Research Title. For example, Senator Tom Daschle (D-S.D.), Chairman of the subcommittee on agriculture research, cited research as chief among several reasons why he voted against final passage of the 1990 Farm Bill. But many more people praised the Research Title. Several Congressmen and Senators cited research as reason to vote for the Farm Bill, especially those members from urban districts with constituents uninterested in farm subsidies. These members looked through the Research Title for environmental, food safety, and competitiveness initiatives to justify a yea vote on the Farm Bill.

Today, I will focus my remarks on three sore points in the bill that I am sure you will hear more about over time: sustainable agriculture; priority setting for research; and pork barrel funding.

\section{SUSTAINABLE AGRICULTURE}

At issue: Should the Low Input Sustainable Agriculture (LISA) program be expanded? What do we mean by sustainable agriculture research?

The LISA program was authorized in the 1985 Farm Bill and received $\$ 4.45$ million in fiscal year 1990. Judging LISA a great success and all too limited in scope, Senator Patrick Leahy (D-Vt.) introduced legislation in the Senate to expand this program. The House soon followed by introducing similar legislation, with the major difference being the definition of sustainable agriculture.

The Senate used the definition of sustainable agriculture from the report "Alternative Agriculture" by the National Research Council: "agriculture that, among other things, reduces chemical use to the extent practicable."

The House used the definition of sustainable agriculture promoted by the U.S. Dept. of Agriculture (USDA) in their Farm Bill proposal: "agriculture that is economically, agronomically, and environmentally sound over long and short periods."

Although similar sounding, the real crux of the debate was whether the LISA program should focus on finding ways to reduce chemical inputs in farming. There were weeks of heated debate in the House Agriculture Committee. In the Senate, Charles Grassley (R-Iowa) led a floor fight to weaken the LISA program, including taking out any reference to reducing chemical inputs as a research goal, an effort that was defeated by a vote of 60 to 32 . Then on to conference, where the battle lines were drawn all over again.

I was worn down by the fight. Considering the broad definition of sustainable agriculture advanced by our opponents, I was compelled to ask, What and how much of USDA research, funded by taxpayers dollars, fails to meet the broad criteria of economic, agronomic, and environmental soundness? It may make a sensational hearing to review all USDA research unable to meet these goals.

\footnotetext{
${ }^{1}$ Majority Staff Aide.
}

My feeling is that if science and education receives $\$ 1.3$ billion, it is all too reasonable to expect that $\$ 4.5$ million be spent on research focused on reducing chemical inputs in farming.

\section{The compromise}

So who won? Like every decision in the Congress, there is something for everyone. The sustainable agriculture subtitle was divided into three chapters. The first chapter retained the Senate definition of sustainable agriculture and expanded the LISA program. The second chapter kept the House definition of sustainable agriculture and set up a competing program.

\section{Chapter l-Best Utilization of Biological Applications (BUBA)}

Chapter One expands the current USDA LISA program established in the 1985 Farm Bill. The Secretary of Agriculture is directed to conduct research and extension programs that reduce use of toxic materials in production; improve low-input farm management; and promote crop, livestock, and enterprise diversification. The program requires that farmers be involved in the development, implementation, and evaluation of all projects receiving assistance. A federal-state matching grant program also is established to encourage states to carry out sustainable agriculture programs and activities. The sum of $\$ 40$ million annually is authorized to be appropriated through Cooperative State Research Service (CSRS).

\section{Chapter 2-Integrated Management Systems}

In Chapter Two, the Secretary is directed to establish a program to enhance research and dissemination of information related to farming operations, practices, and systems that optimize crop and livestock production that are environmentally sound. Producers will be encouraged by the Secretary to adopt and develop individual, site-specific, integrated, crop-management and resource-management practices. The sum of $\$ 20$ million annually is authorized to be appropriated through the extension service.

\section{Chapter 3-Sustainable Agriculture Technology Development and Transfer Programs}

In Chapter Three, the Secretary is directed to develop technical guides, handbooks, and other educational material that describe farm production systems that foster sustainable production systems, Detailed information on selection of crops and varieties, rotation practices, tillage systems, nutrient management systems, soil building practices, pest, weed, and disease management, soil, water, and energy conservation, livestock management, and other information as well as practical instructions to aid producers in adopting sustainable systems shall be provided. Such sums as necessary are authorized to be appropriated.

The Secretary is directed to provide education and training for extension agents and for other professionals involved in the education and transfer of technical information concerning sustainable agriculture. Regional training centers will be designated at existing institutions to provide intensive training for agricultural specialists. Competitive grants will be awarded to entities to conduct workshops to familiarize all other extension agents with basic knowledge on sustainable agriculture. All agriculture extension service agents are to be provided with one of the two types of training in sustainable agriculture no later than 1995. Authorization is set at \$20 million annually for extension service training. 


\section{On the horizon}

If the USDA does not start taking the initiative in sustainable agriculture, someone else will. Officials from the Office of Management and Budget have publicly discussed funding agroecology research at the Environmental Protection Agency if USDA continues to stall. The Big Green initiative is indicative of a trend. The debate will move away from' reduction in pesticide use to elimination if we don't act now.

If the agriculture committees in Congress do not take the initiative in sustainable agriculture, someone else will. I attended a conference in which a leader in the consumer movement referred to the House Agriculture Committee as "the snakepit of pesticide policymaking." The environmental committees will legislate our farmers out of business with tough regulations before the research establishment has come up with the answers farmers need.

\section{The challenge}

I note that LISA is on your society's agenda. This is good, and I urge you to get the message out. Tell USDA, tell the state governments, tell your dean. Clearly, we need a sizable effort to counterbalance the message delivered by the chemical industry. The agriculture research community's credibility is at risk. And let there be no mistake about it-this means that ultimately your ability to obtain funding is at risk.

\section{PRIORITY SETTING}

At issue: Should USDA-sponsored research have social goals? Should priorities be established for USDA-sponsored research?

This past year the big push was for a $\$ 500$ million investment in the competitive grants program known as the National Research Initiative. Clearly it is needed. As you know too well, agricultural research has been level-funded for two decades. There was almost no congressional debate regarding the merits of the increase.

But at the same time Congress was ready to authorize a funding increase, it also was hearing that some criteria needed to be set for research spending. Science for science's sake or science that resulted only in obscure journal publications would not pass muster. Many congressmen argued that, in this time of tough budget choices, there was a great need to assure taxpayers that agriculture research is important to rural communities, the environment, food safety, and other critical issues.

Both the Senate and House Research Titles contained prioritysetting mechanisms in order to tie federally sponsored research to social goals. These mechanisms were not meant to stop any particular research project but rather to establish goals for science that funded research should advance.

\section{The compromise}

A new statement of the purposes of the agricultural research and extension system is set forth: Subject to the varying conditions and needs of States, Federally funded agricultural research and extension programs shall be directed to accomplish the following:

- continue to satisfy human food and fiber needs;

- enhance the long-term viability and competitiveness of the food production and agricultural system of the United States within the global economy;

- expand economic opportunities in rural America and enhance the quality of life for farmers, rural citizens, and society as a whole;

- improve the productivity of the American agricultural system and develop new agricultural crops and new uses for agricultural commodities;

- develop information and systems to enhance the environment and the natural resource base upon which a sustainable agricultural economy depends; or

- enhance human health by fostering the availability and affordability of a safe, wholesome, and nutritious food supply that meets the needs and preferences of the consumer; and assisting farmers and other rural residents in the detection and prevention of health and safety concerns.

The Secretary is directed to establish guidelines to ensure that the purposes expressed in this section are reflected in the prioritysetting processes for research and extension programs such that projects consistent with these purposes are emphasized and each of these purposes is advanced by the research and extension program in its entirety. The statement of purposes is not, however, intended to be used to prohibit any research or line of inquiry.

A new Agricultural Science and Technology Review Board is established. The purpose of the board is to provide technical assessment of agricultural science issues and to consider the impact of technologies on agriculture and the social and economic wellbeing of communities. The Secretary is required to seek the advice of the Technology Assessment Board established in this title on policies, priorities, and operation of the competitive grants program.

\section{On the horizon}

This issue of priorities will come up again and again, not only in agriculture, but across science agencies. In 1991, Senator Leahy and Senator Daschle will hold hearings on priority setting.

\section{The challenge}

We must get over the initial fear that priority-setting efforts are a McCarthy-like witch hunt to sniff out supporters of certain research. This debate must be seen for what it truly is: an effort to establish a simple set of purposes for research, which, if you are not meeting it today, then I suggest it may be time to rethink your agenda.

In your society's own priority-setting process, give some thought to this debate. During the farm bill deliberations, we often were told that, in fact, an extensive priority-setting process is solidly in place. There is little coordination among the societies, Academic Program Committee on Organization and Policy, Experiment Station on Organization and Policy, Extension Committee on Organization and Policy, Agricultural Research Institute, etc. My friends, to the majority of Congress, it is all just agricultural research and we don't understand why there are so many mixed messagesmixed messages that dilute whatever it is you are trying to say.

\section{PORK BARREL FUNDING}

At issue: How should we stem the growth in special project funding in agricultural research and facility construction? Why does this pork barrel funding occur?

I think that we all could come up with a better use of $\$ 500,000$ than for restoration of Lawrence Welk's birthplace-ah, the appropriations process at its best. Why do such special interest projects get funded? First, and most obviously because members want to deliver to the home team.

\section{The compromise}

Grant recipient eligibility for the Special Grants program is broadened to include the following: state agricultural experiment stations; all colleges and universities; other research institutions and organizations; federal agencies; private organizations or corporations; and individuals. A requirement that $90 \%$ of projects funded under special grants be for regional or national problems is also established.

A commission is established to evaluate all agricultural research facilities. The commission shall recommend to the Secretary and to Congress all facilities requiring closure, consolidation, and reinvestment. The commission also shall recommend a rational decision-making process for future facility construction.

\section{On the horizon}

If the pork barrel politics does not stop soon, that is all there will be. Already, if we finished the facilities planned and underway, it would use up almost all of the request for increase in the National Research Initiative. To borrow an old agriculture expression, "we're eating our seed corn."

On specific program authorizations, the perception is that the system is unresponsive and that this is a legitimate action. I dis- 
agree, but I was outnumbered. I say, let's replace specific authorizations with an agreed upon general statement of purpose and let that be that.

\section{The challenge}

Congressmen don't come up with these research ideas in a vacuum. They come from the universities, from the development offices, from their constituents. You point the finger at the Congress; I point the finger back at you. None of us are blameless. It is time to acknowledge the breakdown in the system and fix it. No one supported the facilities effort, not one accolade has been given to Senator Leahy since its passage. Everyone is in great fear of being held in disfavor.

Tell your congressman that you don't want pork. Tell him that if all the dollars that now go to about four states were divided up among the many, we'd all be better off.

\section{CONCLUSION}

We are there at the other end of the phone. It is great to get out and visit with all of you. Also, you are well served by congressional fellows, David Johnson who works with me on the committee staff and George Wilson who works for Senator Terry Sanford (D-N-C.).

Finally, let me urge you to get involved. Few horticulturists attended this Special Session Symposium, especially considering that $>1700$ people were registered for your conference. You had the Assistant Secretary among others here, and it is a great opportunity for informal exchange of ideas. 